\title{
Citizenship Education in Post Modern Society
}

\author{
Jan Pouwels (Hogeschool van Arnhem en Nijmegen, Netherlands)
}

\begin{abstract}
Dealing with citizenship education as a part of formal education, I argue that the international human rights culture and human rights education can serve as a fundamental reference for contemporary citizenship education and that conflict pedagogy is an adequate teaching strategy. I try to draw a picture of how such education can be perceived from a pedagogical and didactical point of view, making a set of recommendations to actualize this perspective on values and citizenship education.
\end{abstract}

Résumé : Dans l'optique que l'éducation à la citoyenneté est une composante de l'éducation formelle, je mets en évidence que la culture internationale des droits humains et que l'éducation aux droits de l'homme peuvent servir de référence fondamentale. Je démontre aussi que la pédagogie de la résolution des conflits est une stratégie d'enseignement adéquate. Je dresse le portrait de la perception d'une telle éducation du point de vue pédagogique et didactique, tout en formulant une série de recommandations en vue d'actualiser cette perspective à l'éducation aux valeurs et à la citoyenneté.

\section{Citizenship and National Values}

Although the notion of citizenship takes us back to the old Greek and Roman cities and the development of cities in the western world in the 13th and 14th century, today the meaning of the word is mainly constituted by the concept of the nation state (Gellner, 1986; Peschar, 1995). The premise, according to Gellner, is the idea of a 'contract' between the individual citizen and the government; a balance between rights and duties in the relationship between citizen and state. Gellner unmasks the state's interest, "nationalism is not the awakening of an old latent, dormant force (...); it is in reality the consequence of a new form of social organisation, based on deeply internalised, educationdependent high cultures, each protected by its own state" (1986, p.48), or as Anderson puts it in a similar way: "nations are conceived as a deep horizontal comradeship" (1991, p.7).

The classical idea of citizenship is built on the supposed cultural homogeneity of people united by state borders, strengthened through education: "The equal access of believers to God eventually becomes equal access of unbelievers to education and culture. The important, identity-conferring part of one's education is not the special skill, but the shared generic skills, dependent on a shared high culture which defines a nation" (Gellner, 1986, p.142). Nations replaced religious culture with uniquely constructed national cultures that are very much imagined and limited (Anderson, 1991). Today, a neo-republican citizenship is 
promoted in my country, The Netherlands, stressing people's ability to make autonomous judgments and to contribute competently, reasonably and loyally to a pluralist democracy; however, citizenship is an essentially contested concept since it is strongly related to economic, social and political circumstances, currently identified with concepts and developments of individualism, globalisation, and a strong division between public and private life (Peschar, 1995, p.229; Winter, 1995, p.48).

Recognizing today's pluralism, ethnic and cultural diversity, personal or group identity, new forms of citizenship must support equality and universality on the one hand and yield to diversity and specific demands and wishes on the other. Citizenship is seriously challenged by internal problems of countries and the concept of social cohesion is frequently used yet, the supposed inner homogeneity of a community of people has always been an illusion (Pouwels, 1998: 21-22). Even in a very small country like the Netherlands, there is great diversity in language, in geography, in religious orientation in village or city life, in tradition and family life.

The challenge of a future citizenship education, to my view, is to find ways to recognize diversity as a precondition and force to change the world and to serve as a base upon which to build new conceptions of citizenship. We must bring all our knowledge and creativity together to change our concepts of community, nation state, citizen, sovereignty and individual responsibility and to elaborate these concepts to realistic (educational) practices. But how can we build citizenship in such diverse countries? And if there is no common local or national culture to relate citizenship to, how can we build common national schools? But should we build common national schools at all in the new world that is ahead of us? These are the provoking questions that lie ahead.

\section{Values and Education}

Concepts of citizenship education hold many explicit and implicit values about life and society. Sometimes they refer to the value of tradition or freedom, or to obedience and respect or initiative, politeness and good behaviour or patriotism. How are we going to determine what values are core values and necessary for children to learn? "The greater part of what my neighbours call good I believe in my soul to be bad, and if I repent of anything, it is very likely to be my good behaviour. What demon possessed me that I behave so well?" (Thoreau, 1995, p.6).

Values like loyalty, respect, dignity can be meaningless, used and misused by everyone and every state. Apart from naming them, we need to say what we mean. This is very hard to do in general terms. Words and meanings of words need also a concrete body of cultural reference. The result of giving real substance to empty shells is that the description or explanation will not be 
applicable in all situations but on the other hand, it will have more impact, in its actual use.

In the history of ethics, the legitimisation of values has moved through nature (natural ethics), outside authorities (prescriptive ethics) and finally through human deliberation (ethics of interaction), whereby values are determined by humans through deliberations and negotiations, which is my perspective.

The culture or environment of the classroom is made up of a myriad of often unrecognized implicit values and practices. For example, there are: interaction between children, interaction between child and teacher, class interaction and class climate, the arrangement of the classroom, the chosen content, teaching strategies, democratic relationships in school management and decision making, the class environment in terms of role of parents, the extended school function, the school climate, the geographical setting of the school, the school as an organisation (institutional curriculum and rules), the formal curriculum, the informal or hidden curriculum, the societal curriculum, the teacher as a filter (subjective work concept), the child's character, the group dynamics (child culture), the language used and the language code, the evaluation, testing and differentiation (Klaassen, 1996, p.75-98). Education is not neutral, but replete with values every single minute.

\section{Conceptualizing Citizenship Education}

Although values are discussed very generally, these can be interpreted very differently with reference to one of the three conceptualizations of citizenship education, as distinguished by Veugelers:

- The adapted citizen who finds discipline, good manners, obedience and social involvement important characteristics;

- The calculating citizen who finds discipline and autonomy, critical thinking and the ability to deal with critics, more important than social involvement;

- The critical-democratic citizen who finds both autonomy and social involvement important including considering other points of view, showing respect for others and showing solidarity with others. Discipline is of lesser importance (2003, p. 6-7).

Veugelers clearly adheres to the third conceptualization of citizenship, a position located in the theory and practice of the Frankfurter Schule, which can be found as well in Dewey's and Freire's pedagogic in today's critical pedagogy, given their foci on autonomy and social involvement.

The Council of Europe has launched the European Year of Citizenship through Education 2005 where democracy should be learned and lived on an everyday 
basis (www.coe.int). This raises the issue of the meaning of the concept of global or world citizenship.

A new kind of citizenship is needed for the 21st century, which Will Kymlicka calls multicultural citizenship. It recognizes and legitimizes the right and need of citizens to maintain commitments both to their cultural communities and to the national civic culture. Only when the national civic culture is transformed in ways that reflect and give voice to the diverse ethnic, racial, language, and religious communities that constitute it will it be viewed as legitimate by all of its citizens. Only then can they develop clarified commitments to the nation-state and its ideals. (Banks, 2003)

It is very difficult to develop a good understanding of citizenship and apply it to contemporary citizenship education; or to prescribe its proper place in contemporary society.

Post-modern philosophy challenges the Western (educational) goal of the autonomous citizen. We are not sure anymore what the world should look like and whether we are on the right track. The loss of certainties that accompanies post-modern thought leads to modesty in conceptions and assertions about the world, people and societies. After 'Auschwitz', the goal of history is suspicious as is the meta-story of consensus and unity that implicates so often terror in its rational enforcement. Nobody knows the absolute truth! What remains is a general belief in the fundamental human dignity and the search for 'prudent justice'. There is also a more moderate attitude in Western society towards other cultures and our own cultural superiority. In our highly mobile society (at least for a large number of people), feelings of uprootedness, dislocation and feeling a migrant ourselves in a fast changing world, illustrate post-modern reality.

The concepts of 'citizen' and 'citizenship' are as unclear as the concept 'postmodern', since there is such a great difference in describing a (good) citizen. Diversity is a keyword in describing today's citizens. The post-modern reality pulverizes the illusion of homogeneity and seems to become instead the acknowledgment of physical and mental diversity inside one (ethnic) culture and between many different (ethnic) cultures in one (national) society, known as the pluralist society.

Furthermore we look at the history of citizenship and its relation to the idea of a nation state and national values. We conclude more or less that men should be very careful and modest in determining national citizen values in a multicultural and post-modern society. The conceptualization of citizenship education seems necessarily confined to national values and we doubt whether it can represent the civic society to which it is developing. We know that values that support specific national concepts of citizenship have their own power interest and can be one-sided and dangerous. 


\section{Human Rights Education: Disobey Unjust Orders}

The prime reference for citizenship education in the 21 st century lies in the human rights culture. The words and meanings of the international human rights culture are abstract but these can and should be transformed to local, regional and national practices. The international human rights culture and especially the Convention on the Rights of the Child (CRC) is the yardstick for contemporary citizenship education. The Human Rights Culture project has an old and very respectable history (Cliteur, 1997), with WW I and particularly World War II definitely giving momentum to the project, especially with the Universal Declaration of Human Rights (UDHR), of 1948, now translated in over 300 languages and still being the prime reference for world politics and ethics. The UDHR is intended to serve but one purpose: never again! No fascism, no war! Never!

... human rights are not so much the declaration of the superiority of European civilizations as a warning by Europeans that the rest of the world should not seek to reproduce its mistakes. The chief of these (mistakes) was the idolatry of the nation state, causing individuals to forget the higher law commanding them to disobey unjust orders. The Declaration is "...a studied attempt to reinvent the European natural law tradition in order to safeguard individual agency against the totalitarian state." (Ignatieff, 2001, p.65-66)

After this key document, many other UN treaties arrived, with conventions adopted on individual, civil and political, social and economic rights, going on further to women's, indigenous people's, and children's rights. All these categories of people were to be protected, to maintain their agency, and to be empowered to enjoy their inalienable human rights.

From the human rights perspective, the protection of children up to the age of eighteen, starts with the Geneva Declaration of 1924 proclaimed in the General Assembly of the League of Nations. Children were given rights for the first time in history. The Declaration of the Rights of the Child of 1959 was an extended document, more detailed and new principles were added. In 1989, the Convention on the Rights of the Child (CRC), containing fifty-four articles, was adopted and signed, going into force after ratification by twenty countries. Today 189 of a total of 191 countries in the world have ratified this Convention, though some with reservations ${ }^{1}$ and it is by far the most agreed upon international soft law in existence (Verhellen, 1997). Even more than the UDHR and its treaties, the CRC focuses on protection rights, provision rights, participation rights (the three P's) and extra care rights. The CRC is the first document in history that recognizes the right of children to participate in society

\footnotetext{
${ }^{1}$ See website http://193.194.138.190/html/menu2/6/crc/treaties/declare-crc.htm.
} 
(Winter, 1995, p.61). This corpus of rights serves as basic reference for citizenship education.

\section{Citizenship Education as Human Rights Education}

Over the years I have tried to develop a human rights culture in teacher education by focussing on children's rights as mentioned in the CRC. I feel strongly supported by the UN Decade for Human Rights Education and its follow up. The great work of hundreds of people in the world includes: a right to education for all children, which means the right and the opportunity to develop relatively free from adult responsibilities but learn to participate in a complex adult life none the less. National governments and their representatives, including teachers, are responsible for making learning and education possible. Although article 42 of the CRC is very clear about the responsibility of the state, to make the principles and provisions of the Convention widely known, by appropriate means to adults and children alike, in my country and many more countries, informing children about their rights is not a part of the school curriculum.

Why does the school not inform the children about their rights? Competencies such as co-operation, inquiry learning, identifying concepts, deliberation and communication, critical thinking, assertiveness and action, are important to the development of a human rights culture. And finally in the educational approach that fully includes HRE in the educational process, we not only tell the children about their rights and practice certain skills, but we try to rearrange our teaching strategies by respecting children as fellow citizens who have a voice.

Children's rights comprehensively described in the CRC can, to my opinion, act perfectly as a basis for education. It stresses an element of protection that we hold true for children, an element of provision to grow in different ways, the element of extra care in situations beyond children's responsibilities and it stresses the need for participatory learning experience. Human rights education is very close to the three conceptualizations of citizenship education when using participatory learning methods to develop the use of participatory rights. I believe that citizenship education can benefit from linking up with human rights education and overcome its inherent limitations.

\section{Using Conflict as a Teaching Strategy}

Like any community -including states and nations-, schools have a tendency to ignore and deny conflicts and to keep up a neutral appearance and try to be harmonious institutes where everyone feels fine. This is what I would call an illusion! There are, of course, no objections against a group of people or a school for having a starting point or reference of values-on the contrary- but this 
may never be the core goal of formal education. Dasberg calls this type of (school) education 'socialisation' in community values, which is necessary to some extent. But real education is something different. It has an ethical task: to teach children to become critical members of society and to strengthen them to develop their own future ideal, a new world (Dasberg, 1993). Education should create cognitive, social and moral conflicts which are the ultimate foundations for learning. But the contrary is the case. Formal education is too much devoted to avoid conflicts, to stay neutral and link up with (middle of the road) family or society values. This 'school-attitude' is reproducing 'old' society members instead of empowering 'new' members for a new future. The main task of a school, as a community environment, is to recognize and benefit from the great diversity, dissonance and singularity in competence and life expectations and to deal with or to create (cognitive, social and moral) conflicts and to learn from these.

Education has an ethical task as well as the task of socialization: to teach children to become critical members of society and to strengthen them to develop their own future ideal, a new world (Dasberg, 1993). Education should create cognitive, social and moral conflicts which are the ultimate foundations for learning, empowering children and youth for a new future. The main task of a school, as a community environment, is to recognize and benefit from the great diversity, dissonance and singularity in competence and life expectations and to deal with or to create (cognitive, social and moral) conflicts and to learn from these.

What I have tried to do in teacher education in what I call 'values oriented education' is to make (moral) diversity visible, explicit or discursive by using it in concrete lived experience in and outside the classroom. Delivering 'values oriented education', a teacher has to put up his own values for discussion. He will have to take the view of the child seriously and he is not afraid of conflict or confrontation. He is prepared to start a dialogue aimed at thinking, working and acting together. He should be able to 'see' the moral perspective in every day life, ask the right exploratory and communicative questions and create an environment "... in which children do not have to be afraid to say what they think and show what they do. In which they are not laughed at for being different, but where being different is acknowledged as the source and necessity for living together" (Pouwels, 1998, p. 33). The classroom is full of diversity, if it is allowed to be there. Values oriented education is a way to take this treasure on board and use it as a starting point for lived experiences in living together and deciding together.

Looking at the function of a school, I truly believe that school is a place where children should be confronted with conflicting truths and conflicting values in order to develop knowledge, skills and attitudes to solve these conflicts in a nonviolent way. As Leersen proposes, "a community is not the unity of joint action where people agree with each other, do and decide things together, no, a 
community is that unity of joint action where people disagree with each other and talk problems over" (1998, p. 130), in other words, a place where you learn to deal with conflicts in yourself, in your life and the world. Raising cognitive, emotional and social, materialistic and political conflicts is the best way to solve intellectual, living together and community problems. Democracy is conflict resolution without violence! Yet, teaching children how to solve conflicts by using conflicts has only recently been recognized as educational method in the Netherlands. That is human rights education and citizenship education. This is not the right place to describe the conflict teaching strategy in detail though the reader might find this very interesting. Within the English speaking countries Gerald Graff (1992) is a fine reference to understand the meaning of teaching the conflicts.

Education should never deny the importance of family, community, local and national culture, - it is the starting point - but it should take the challenge, the conflict, the indefinite as a tool for further learning processes to let diversity, strength and power, grow. The school and the teacher is not just teaching about society. It is society, in a special way! This kind of education will surely contribute to a post-modern identity-formation, including education to citizenship. Such an education acknowledges the uncertainty of uprootedness and dislocation; and it starts an investigation, with the things we do know, into the richness of conflicting diversity. Education must find ways to develop pedagogy of acknowledged inequality (pedagogiek van de erkende ongelijkheid) of pupils, students and teachers.

\section{Recommendations towards a contemporary ‘citizenship’ education}

To summarize, values education within citizenship education is to be explicitly related to the human rights culture within formal curriculum, be it within specific subject matter, across the curriculum, as school projects, within democratic pedagogies, attainment targets. Each country has to find out the best way of implementing the human rights and children's rights culture in the curriculum, using article 42 of the Convention on the Rights of the Child and article 28 and 29 of the Universal Declaration of Human Rights.

All teacher education programmes must include human and children's rights culture in the curriculum. Being professionals and states executers of formal education, teachers must be well aware of the rights of children. Future teachers as well as seasoned senior teachers must take leadership in developing human rights-based teaching approaches which recognize the right for protection, provision, extra care and, above all, participation of children, for a citizenship education of quality.

Schools, parents, teachers and children must have opportunities to govern, negotiate, discover interests and defend the ones they think are important. All 
participants of the school community, above all the children, must learn to take a stand and criticize existing relations.

Let children participate in meaningful learning activities and social activities. Let them communicate with each other and decide on individual or mutual tasks. Let them take responsibilities and give opportunities to defend the choices they have made.

\section{References}

Anderson, B. (1991). Imagined communities: Reflections on the origin and spread of nationalism, revised edition, London and New York: Verso.

Banks, J.A. (2003). Educating global citizens in a diverse world, http://www.newhorizons.org

Cliteur, P. B. (1997). De filosofie van de mensenrechten. [The philosophy of human rights]. Nijmegen: Ars Aequi Libri.

Dasberg, L. (1993). Meelopers en dwarsliggers. [Followers and troublemakers]. Amsterdam/ Hoevelaken: Trouw.

Gellner, E. (1986). Nations and nationalism. Oxford: Basil Blackwell.

Graff G. (1992). Beyond the culture wars. How teaching the conflicts can revitalize American education. Norton \& Company, New York.

Pouwels J. (1998). Diversity : A challenge for parents and schools. In H. Grassler, \& J. Pouwels (Ed), How to be a teacher in a Europe of human rights. Nijmegen: HAN Press.

Ignatieff, M. (2001). Human rights as politics and idolatry. Princeton: Princeton University Press.

Klaassen, C. (1996). Socialisatie en moraal. Onderwijs in waarden in een laat-moderne samenleving. [Socialisation and morals. Education and values in late-modern society]. Leuven Apeldoorn: Garant.

Kymlicka, W. (2002). Contemporary political philosophy. Toronto: Oxford University Press.

Peschar, J., \& Wesselingh, A. (1995). Onderwijssociologie. (Sociology of education). Groningen: Wolters-Noordhoff.

Thoreau, H. D. (1995). Walden or life in the woods. New York: Dover (Original, 1854).

Verhellen, E. (1997). Convention on the rights of the child: Background, motivation, strategies, main themes. Leuven Apeldoorn: Garant.

Veugelers, W. (2003). Waarden en normen in het onderwijs. Zingeving en humanisering. Autonomie en sociale betrokkenheid. [Values and norms in education. Autonomy and social participation]. Inaugural address. Utrecht: Universiteit voor Humanistiek.

Winter de M. (1995). Kinderen als medeburgers. Kinder-en jeugdparticipatie als maatschappelijk opvoedingsperspectief. [Children as fellow citizens]. Utrecht: De Tijdstroom. 